\title{
ORIGINATING VISIONS AND VISIONARIES OF THE REA
}

\author{
Helen Allan Archibald \\ United Theological Seminary of the Twin Cities
}

\begin{abstract}
One hundred years ago an assembly of four hundred met at Chicago's Auditorium Hotel to create the Religious Education Association. This article traces the influences of William Rainey Harper, John Dewey, and George Albert Coe in the REA's formation, and explores social and intellectual conditions shaping this movement in its beginnings. The author highlights contributions of George Albert Coe as the leading theorist in the religious education movement from the beginnings of the REA into the middle of the $20^{\text {th }}$ century.
\end{abstract}

One hundred years ago in February 1903 an assembly of four hundred "educational demi-gods" met at Chicago's Auditorium Hotel to create the Religious Education Association. The gathering was convened by the Council of Seventy, a learned society of biblical scholars, upon the urging of the renowned first president of the University of Chicago, William Rainey Harper. ${ }^{1}$

Harper persuaded forty-five presidents and deans of colleges and seminaries to add their names to his own in the invitation announcing the purpose of the convention. The purpose was simple but comprehensive: to improve the religious and moral instruction of American youth, an instruction seen as woefully inadequate and imperfectly correlated with the new learning in history, literature, and the sciences.

It was Harper's imperial mind, ranging in educational interest from the Chautauqua liberal arts program to the creation of a university center of graduate studies; from his scholarly publications in the Hebrew Bible to his teaching in the Hyde Park Baptist Sunday school, which conceived the idea of such a gathering and planned the program enlisting the talents of colleagues through-

${ }^{1}$ A full report of the program, texts of all addresses and committee and membership lists are given in the Proceedings of the First Annual Convention of the Religious Education Association, February 10-12, 1903; the Proceedings of the REA during its first decade give richly detailed information. Shaliler Mathews used the phrase "educational demi-gods" to describe the 1903 participants in his 1928 article, "Inception of the REA" in Religious Education 23: 619-621.

Religious Education Vol. 98 No. 4 Fall 2003
Copyright () The Religious Education Association ISSN: 0034-4087 print DOI: $10.1080 / 00344080390244856$ 
out the nation. As he brought Baptist piety and secular learning together to create the great University of Chicago eleven years before, he sought in this convention to bring together scholars, educators, and churchmen who could create new educational patterns for the local church school, the public school, the college, and the home.

The four hundred participants, almost without exception white, male, Anglo-Saxon Protestants, ${ }^{2}$ joined in hymn and prayer before hearing the first evening's papers on the next steps in religious education. In his opening address President Angell of the University of Michigan stressed that those present were already persuaded that psychological and pedagogical studies had contributed much to secular education and that the time had come to permit these studies to transform religious education as well. Intellectual advances in nearly every field had made thoughtful people aware that the new century was to be a time of transition. Although, as Angell noted judiciously, every period is a time of transition, the present transitional crisis was more portentous for religious education than any in nearly a century.

It was not merely that the new learning, emanating from the great universities like those over which Angell and Harper presided, was challenging the conventional and popular pieties of the Sunday school. It was the whole configuration of educational institutions put together by Protestants at the beginning of the nineteenth century which was being challenged by the literary and historical criticism of the Bible. After the Revolutionary War and following the period of state disestablishment of churches, Protestants sought to find new forms for transmitting their religious faith across the generations. From 1805 to 1830 Protestants created a distinctive pattern of education. It was composed of institutions with clear historical antecedents, but in their interrelationships and in the way they functioned in the broader American society of the nineteenth century, they represented something genuinely new in the history of education. The configuration included an American version of the English charity school, the Sunday school; the denominational college, narrower in sponsorship and aim than the

\footnotetext{
${ }^{2}$ Caroline Hazard and Mary E. Wooley, presidents respectively of Wellesley and Mount Holyoke Colleges, were original members but did not attend the 1903 convention; in 1904 Hazard was elected one of the sixteen vice-presidents of the REA and the Roman Catholic Bishop of Peroria, John L. Spaulding, was elected to the Council of the REA the same year; however, the members, the tone and the preoccupations of the early conventions are overwhelmingly male and Protestant.
} 
colonial college; the truly innovative institution, the Protestant seminary, of which Andover (1818) was the pioneer; and the home. The common school crusade of this same period, led by Protestant churchmen and lay reformers, won popular support for state supported and supervised public schools which were looked upon as part of this larger educational ecology. The public schools were given the responsibility for teaching the common core of Protestant doctrine and morality; the denominational college and seminary provided the instruction in what was distinctive in the various Protestant traditions; and the home carried the chief responsibility for nurturing the sentiment and will on which all character was thought to be based (Lynn 1972). The Bible, the accepted standard of authority for all Protestants, was the key to religious training in all these institutions, the home, the school, the college, and the seminary. What Harper, Angell, and the distinguished company gathered in the Chicago Auditorium Hotel on February 10, 1903 perceived was that the traditional Bible, understood as the very word of God, the center of Protestant religious authority and the source of Protestant piety, was disappearing from the world of Protestant scholarship. The dogmatic Bible increasingly being banned from the public schools, was also being challenged at the seminary level by the assured results of more than a half century of German higher criticism of the Bible. Harper, a renowned Hebrew scholar, had himself brought the new textual critical study of the Bible to Yale Divinity School in 1886. He had, too, a remarkable gift for popularization and in his Bible study guides for the laity he sought to deflect interest from what the higher critics had taken away-Mosaic authorship of the Pentateuch, a relatively smaller matter; and the inerrancy of the scriptures as a whole based on divine authorship throughout, a much greater matter-by drawing attention to what the critics had established. Harper shared the conviction expressed by Rush Rhees, president of the University of Rochester, that whatever theories of biblical revelation were undermined by modern textual and historical criticism of the Bible, the fact that the Bible had survived because it inspired was established beyond all doubt. Shailer Mathews, a theologian brought to the Divinity School of the University of Chicago by Harper, recalled years later that Harper was motivated to convene the 1903 conference by the actual problems he encountered teaching in the Hyde Park Baptist Sunday school; however, his service on the Chicago Board of Education, as well as his scholarly interest in trans- 
forming biblical study in both seminary and college also contributed to his motivation (Goodspeed 1928).

Harper proposed the idea of a national conference on religious education in 1902 to a learned society of biblical scholars, the Council of Seventy, which he had organized in 1895. The purpose of the Council was to promote the historical, philological, and comparative study of the Bible in the light of other ancient literatures. Endorsing Harper's proposal, the Council in October 1902, appointed a General Committee to plan for a national convention composed of Harper, Shailer Mathews, and George L. Robinson of McCormick Seminary in Chicago. Harper also chaired the program Committee whose other two members were Josiah Strong who, since the publication of his book, Our Country, in 1885 was a persistent though conservative advocate for the social interpretation of Christianity, and Samuel T. Dutton, professor of education at Teachers College, Columbia University in New York City.

Frank McMurray, also of Teachers College, served on a three member Invitations Committee. McMurray, one of the founders of the National Herbartian Society, participated the year before in the reorganization of the Society into the National Society for the Scientific Study of Education. He also established an experimental Sunday school at Teachers College on the plea of faculty parents that they wanted a religious education for their children analogous intellectually to the weekday education they were receiving at the College's laboratory school. Albion W. Small, professor of sociology at the University of Chicago, and Philip S. Moxom, a pastor with a long interest in education, were the two other members.

George Albert Coe, who held the John Evans professorship in moral and intellectual philosophy at Northwestern, served on the Arrangements Committee. Coe, just past forty, was moving steadily in his professional interests from philosophy in which he received his Ph.D. in 1891 to experimental psychology, and was ready in the winter of 1903 to turn the corner into a new career as a religious educator. Young in terms of this new interest, Coe would grow old with the Religious Education Association organized in the conference's last session, living almost to the eve of the REA's fiftieth anniversary.

Many of the participants in the conference were to achieve careers that won them a permanent place in American social history. John Dewey, already in his mid-forties, with the epochal Studies in Logical Theory just completed, yet, like Coe, still only at less than mid-point in a long life, was to become the most famous. But in addition to those mentioned earlier, the names of many of the original 
members of the Association were to become familiar in American religious and educational history. In any account of the religious history of the era the names of Edward S. Ames, Irving King, Edward Diller Starbuck, and Graham Taylor must figure; and the names of Frederick Eby, Herman Harrell Horne, and James E. Russell are familiar to the student of American education history. ${ }^{3}$

Following the hymn, "When Morning Gilds the Skies," at the opening of the second session of the conference, Coe, Dewey, and Starbuck gave their addresses on "the modern conception of education." Coe and Starbuck traced religious education as a part of general education, noting that traditionally all education had been controlled by a religious conception of the aims of human life. The distinctively modern differentiation between religion and education emerged when the nation state became the sponsor of an education conceived as the universal right of all, a process which Coe would elaborate in Education for Citizenship thirty years later. Following their addresses, Dewey spoke on religious education as conditioned by the principles of modern psychology and pedagogy.

For Coe, this association with Dewey was to be the beginning of a life-long intellectual companionship although there is no evidence that they ever knew each other personally. Coe acknowledged in many of his writings his indebtedness to Dewey's thought and rejoiced publicly when Dewey's A Common Faith (1934) gave him grounds for his conviction that even Dewey's mature instrumentalism did not preclude recognition of the religious as an enduring aspect of human experience. But while the conference marked a life-long commitment to religious education within the context of the historic church and under the conditions imposed by modern science and democracy for Coe, for Dewey it seems to mark as clearly a final turning away from all institutional religion and any education conducted under its sponsorship. ${ }^{4}$

${ }^{3}$ In his 1972 A Religious History of the American People, Ahlstrom cites Ames, King, Starbuck, and Taylor in his index; James Russell was the first dean of Teachers College, Columbia University; Frederick Eby, among other works, authored The Development of Modern Education with C.F. Arrowood; Herman Harrell Horne, Professor of Philosophy and Education at New York University from 1909 to 1940, wrote The Democratic Philosophy of Education, Companion to Dewey's Democracy and Education: Exposition and Comment in 1932.

${ }^{4}$ According to Jane Dewey her father did not transfer his church membership when he moved to New York City in 1904, "Biography of John Dewey" in Schilpp, 1939; Dewey was elected to the Council of the REA in 1904 but his name does not appear on membership lists after that year. 
In his address Dewey observed that modern psychology has no special revelation of its own to deliver to religious educators, but it can help interpret and illuminate certain general considerations. Modern psychological theory stresses the principle of growth and the consequent successive expansions of experience at different levels. The child with his own distinctive emotional and mental outlook must be helped to experience the truly religious aspects of his own growing life. The most serious handicap to religious education is the assertion that the spiritual and emotional experience of adults is the appropriate norm for the child's religious life. He advised religious educators to return to Jesus' teaching of the successive stages of growth-first the seed, then the blade, finally the ripening ear of corn. He ended his paper with the observation that the most fundamental of all educational questions concerns the moral and religious growth of persons.

Dewey was as ready as any of the participants in the conference to use biblical phrases-learned long before in the context of a gospel of crisis and redemption-to underscore the contemporary principle of continuity. Nearly all those who addressed the conference were men who had received their education in the eighties and, to use Dewey's phrase, the impact of Darwin on their thought was deep and lasting. In one way or another each of the speakers emphasized continuity between human beings and nature and the continuity throughout the physical, mental, and moral growth of persons. But, despite this similarity, Dewey's remarks have a certain pro forma quality about them which distinguishes them from the enthusiastic addresses of the other speakers. His words suggest that he had inwardly withdrawn from the ideal which animated Harper and the conference which he had brought into being. How far Dewey was beginning to move from the purposes of the conference and from his own preoccupations when he wrote, "The Obligation to the Knowledge of God," in 1884 is seen in an article he published in 1908, in which he wrote of the problems of religious educators as an interested but detached observer.

Harper, an indefatigable textbook writer, anticipated that the conference addresses would be what he called "a great textbook for the world." Read now, these addresses make clear that the conference as a whole was designed to establish the possibility that the Protestant educational configuration could survive into the twentieth century by means of the very scientific scholarship which threatened to destroy it. Harper had frequently participated in Methodist Bishop John 
Vincent's extraordinarily successful attempt to transform camp meeting fervor into educational channels through summer institutes at Lake Chautauqua. (Lynn and Wright 1974) The February, 1903, gathering - perhaps significantly not in a summer setting of outdoor beauty, but in the urban mid-winter-can be seen as an attempt to do the reverse: to enkindle the new disciplines of psychology and pedagogy with evangelical purpose. The representatives of the educational establishment gathered at Chicago saw clearly that the transformation of the dogmatic Bible into the historical Bible of late nineteenth century scholarship created an educational crisis which threatened the infrastructure of the whole educational system. Members of mainline Protestant denominations, confident that their faith complemented modern advances in science and society rather than opposing them, they were seeking some new infallible standard of their own to give stability in the contemporary educational situation.

It was their recognition of the inevitability of having to let go of the public school and the college from the ecology of Protestant educational institutions which explains the fervent devotion to the Sunday school of Harper and so many others at the conference. Under the intellectual and social conditions of the new century, the Sunday school would have to become a true school if it were to do the work which was now thrust upon it. George Albert Coe responded directly to this challenge to professionalize the church's education and make it the equal to the best in the new secular education. As the leading theorist of the religious education movement over the next forty years, he is representative of all those who in 1903 were willing to permit standards emerging from within the culture to reshape the church's own patterns of nurture, and even, the church's message itself. After all, as a United States Commissioner of Education put it in 1907, was not the best in American culture a kind of "overflow Christianity"? In letting the best in that culture guide him, Coe testified that he saw this best as perfectly compatible with his Protestant faith. During the next two and a half decades of his life Coe redefined the educational mission of the liberal Protestant church. In a long retirement that lasted another quarter century, he defended that mission against attacks that came from a more aggressively secular society than the gentlemen of 1903 could have imagined and from a renascent orthodoxy within the circles of religious liberalism which they could only with equal difficulty have surmised (Cully 1965).

In the winter of 1903, however, all this was still in the future and 
at the conference Coe was among colleagues, who, drawing their inspiration from many sources, were then united in the conviction that they were launching a movement whose time had come. Coe summed up his understanding of the intellectual sources which contributed to this unity of outlook of the majority in a paper, "The Philosophy of the Movement for Religious Education," published in 1904. Far from casting a backward glance at the Egypt of the old educational configuration, Coe saw the religious education movement with which he had already identified himself as irrepressible in its creative potential for establishing a new paideia.

Coe interpreted the philosophy of the movement for religious education as growing out of psychological, sociological, and philosophical assumptions controlled by the principle of evolution and an immanental-personalist theology which was fully compatible with the same principle. These great intellectual themes always fascinated him more than the practical aspects of religious nurture and he elaborated them in his major books, The Psychology of Religion (1916), The Social Theory of Religious Education 1917), Motives of Men (1928), and his last book, What is Religion Doing to our Consciences? (1943).

Two themes significant for Coe's later development of religious education theory are not explicitly touched upon in his 1904 essay. Science in the form of biological evolution does, of course, figure prominently; but science in its most general sense as method-what Coe would later call "the democracy of the intellect"-is absent. Absent, too, is the concept of democracy, a concept which Coe would later socialize and spiritualize so as to make it almost synonymous with Christianity. That such general themes were already much in the air, and indeed, constituted the new century's "climate of opinion," is revealed in an address delivered to a joint session of the Religious Education Association and the National Educational Association in July 1907. The speaker was the then Commissioner of Education, Elmer Ellsworth Brown, who was elected to the Council of the REA in 1904.

Brown began his address by noting that the methods employed in education must always follow upon and complement the interests of the wider society. In the middle ages institutional religion dominated society and its methods controlled education; but the "centralizing and unifying fact of modern civilization," Brown told the nation's teachers, "is science, a science which is the same the world over." Contrasted with this universal science, the parochialism of religion, split 
as it was into many competing sects, was highlighted. The one universal feature of the Christian religion was its teaching of the "brotherhood of man under the fatherhood of God" and this had already found social expression in democracy. A new moral consciousness was dawning in science's devotion to truth and democracy's devotion to human equality, a consciousness so profound that it was already transforming the methods and spirit of general education; in time, it would transform religion as well. When the transformation was effected religion and education would be free to find their universal, and Brown strongly prophesied, their unified expression. Thus buoyed up by an optimism coming from the synthesizing idealism so characteristic of the period, and spurred on by the need to strengthen the educational ministry of the church spelled out so clearly at the 1903 conference, Protestant ministers, and laymen plunged actively into the religious education movement. Soon the movement gave birth to curricular and methodological guides for the church and a new academic discipline for the seminary. The mood of religious educators was ebullient and some even began to believe that in their own brand of liberal Protestant faith they possessed the higher synthesis which Brown anticipated.

John Dewey, however, kept aloof from such facile hopes. In 1908, he gave a sober warning to religious educators carried away by the belief that "the religion of the future" was already upon them (Dewey 1908).

Dewey began his essay by disavowing any appeal to those who are already committed to special dogmas of religion or who believe "that religion is a monopoly or a protected industry." He spoke directly to the religious educators who took as their own the philosophy of the movement as outlined by Coe in 1904 and whose premises denied any breach between humanity, the world and God. When such educators seek "special religious education at special times and places", then, he confessed, "a sense of unreality comes over me." They seem to say, he continued, that since religion is a

... universal function of life, we must particularly safeguard it lest it disappear; that since religion is the consciousness of the spiritual import of experience, we must find mechanical appliances for developing it.

Dewey accepted the theoretical possibility that the antinomy between "coming to know" in science and religion could one day be overcome. On that day, a "grace and sanction" lacking in the culture since the dissolution of the medieval synthesis would be restored. But 
however desirable it might be, that end, he warned, was very far from view in the first decade of the twentieth century. He cautioned his readers to remember the long history behind present-day religions and to expect a long, slow maturation period for the new religion. The transformation of historical religion into a religious awareness that would be the "flower and fruition of the human spirit" would only slowly emerge from within modern culture.

It is not clear in Dewey's essay whether the future religion "thoroughly naturalized in the hearts and minds of men so it can be considered publicly, openly, and by common tests" will be a humanized Christianity or an entirely new faith. Dewey was not directly concerned with this problem in the essay and he advised religious educators not to worry about the shape of the new religion. He called upon them to devote themselves persistently and patiently to "the development of the ideas of life which lie implicit in our still new science and our still newer democracy."

No contrast could be greater than the expectant mood of the visionaries of 1903 that religion would accommodate itself to the claims of science and democracy and the mood of the early years of the twentyfirst century. The present culture celebrates religious diversity, not unity; today there is skepticism that universal religious principles can be extracted form the richness of religious particularity. The ethnic, the cultic, and the ritual aspects of religion now claim people's loyalties as once the hope of a new religion claimed their imagination.

Nor was it to come to pass as many, including Coe, expected that the religion of the future would bear a close resemblance to their own liberal Protestant Christianity shorn of all dogma.

All the historic religions seemed in 1903 to be leaving the world scene to make room for what Dewey would later call "a common faith;" but the historic religions grew throughout the twentieth century assuming new forms and gaining new adherents. Religions in their historicity, in their doctrinal distinctiveness and in their ritual particularities were to re-emerge with new vigor as the twenty-first century dawned.

In this hundredth anniversary year of the REA, it is scarcely conceivable to us that the presidents of great universities, renowned philosophers, psychologists, theologians and church leaders would be major participants in a conference on religious education. In retrospect, the 1903 gathering assembled by Harper and the REA's achievements in its first decade represented a last hurrah of the Protestant 
establishment as it sought to make its own imprint upon American religious culture.

The vision of the REA as the great clearing house of research and information never materialized; soon the comprehensive organization with its numerous departments, among them departments of Universities and Colleges, Theological Seminaries, Secondary Public Schools, Elementary Public Schools, Home and Libraries, gave way to a small office presided over by an Executive Secretary. The grand vision faded before the reality of limited funding; but, however reduced its fortunes, the REA never ceased the publication of its scholarly journal, Religious Education.

The REA today may have less expansive goals and less prominent leadership than it possessed in its first decade; but it continues the original vision to find the common ground between religion and education. And in one vital respect the REA of the twenty-first century is more universal: today it brings Catholic, Jewish, and Protestant educators together in greater parity and it includes Islamic educators and educators from the non-biblical religions now growing in the United States.

There was much pomp and ceremony surrounding the founding of the REA in 1903, but it could be argued that the nation to which it was addressing itself was already changing. Now a century later, a smaller, leaner REA has itself changed but may well be better poised to serve a religiously diverse America with a praciticality that might well bring satisfaction to that far-seeing visionary, William Rainey Harper.

Helen Allan Archibald is an Associate Professor Emerita at United Therological Seminary of the Twin Cities, New Brighton, Minnesota. Email:suzachap@aol.com

\section{REFERENCES}

Ahlstrom, Sydney. 1972. A religious history of the American people. New Haven: Yale University Press.

Brown, Elmer Ellsworth. 1907. Some reflections of religious education and secular education. Religious Education 2:121-126.

Coe, George Albert. 1904. The philosophy of the movement for religious education. The American Journal of Theology 8:225-239. 
Cully, Kendig Brubaker. 1965. The search for a Christian education - Since 1940. Philadelphia: Westminster Press.

Dewey, John. 1884. The obligation to know God first appeared in the Student Christian Association Publication of the University of Michigan; reprinted in 1969 in John Dewey: The early works, 1882-1892. Carbondale and Edwardsville: Southern Illinois University Press.

Dewey, John. 1908. Religion and our schools. Hibbert Journal July 1908; reprinted in Joseph Ratner. ed. 1939. Intelligence in the modern world: John Dewey's philosophy. New York: Random House.

Goodspeed, Thomas W. 1928. William R. Harper: First president of the University of Chicago. Chicago: University of Chicago Press.

Lynn, Robert W. 1972. The uses of history: An inquiry into the history of American religious Education. Religious Education 67:83-97.

Lynn, Robert W. and Elliott Wright. 1971. The big little school: Sunday child of American Protestantism. New York: Harper \& Row.

Religious Education Association. 1903. Proceedings of the First Annual Convention of the Religious Education Association, February 10-12, 1903. Chicago: Executive Office, Religious Education Association.

Schilpp, Paul Arthur. 1939. The philosophy of John Dewey. Evanston and Chicago: Northwestern University. 